\title{
Greening the Sri Lankan Trade: Tariff Policy Liberalisation in Non-Plantation Agriculture and the Environment
}

\author{
W.G. Somaratne ${ }^{*}$
}

\begin{abstract}
Sri Lanka has implemented major trade policy reform measures to create an internationally competitive environment for the Sri Lankan agricultural and manufacturing products, during the last two decades. However, the policy analysts have not paid due attention to the likely economic and environmental impacts of trade policy liberalisation, including reforms to be undertaken within the framework of the GATT/Uruguay Round Agreement on Agriculture (GURAA), the South Asian Preferential Trading Arrangement (SAPTA), and the South Asian Free Trade Area (SAFTA).

This paper analyses the likely macro and meso economic effects and agro-environmental effects of tariff policy liberalisation as a 'green' policy device within the policy framework of GURAA, SAPTA and SAFTA, using an appropriately modified computable general equilibrium (CGE) model of the Sri Lankan economy. The general equilibrium approach is chosen because many of the policy changes have economywide ramifications.

The focus of the paper is mainly on the tariff liberalisation, nonplantation agriculture and land degradation-induced environmental management in the hilly regions of Sri Lanka. Proper management of land in the non-plantation agriculture sector is particularly of importance as policyinduced changes in land use patterns in the hilly region impact directly on downstream-irrigated agriculture, and hydropower generation. This model extends previous CGE models of the Sri Lankan economy by further desegregating the agricultural sector by regional land types and crops, and
\end{abstract}

\footnotetext{
* Senior Research and Training Officer, Hector Kobbekaduwa Agrarian Research and Training Institute.
} 
explicit incorporation of on-site and off-site impacts of land degradation. The analyses show that trade policy liberalisation, within the policy framework of GURAA, SAPTA and SAFTA have benign macro, meso economic and 
environmental impacts. Hence, tariff policy liberalisation can be categorised as a 'green' policy device. However, inspection of their quantitative effects on environmental variables indicates that there is a potential for additional and complementary economic and environmental policy options to combat micro level agro-economic issues and land degradation.

\section{Introduction}

Trade liberalisation has become a prime component of economic policy reforms in both developing and developed countries in recent years. In the case of the world's developing countries, they pursued an Import Substitution Industrialisation (ISI) strategy from the 1950s, but failed to achieve rapid economic growth to eradicate rural poverty and to minimise environmental degradation. The few developing countries, particularly in East Asia, which undertook trade policy reforms, and adopted an export-led growth strategy, particularly in line with the strategy of regional integration, succeeded in registering fast economic growth and industrial development. In the case of developed countries, this represents the culmination of an ongoing process of both domestic and external policy liberalisation since the end of the Second World War. It is also a central plank of the policies that are being adopted by the previously centrally planned 'transitional' economies as they move to establish market-oriented economies.

In developing countries, the issue of trade policy reforms must be considered in the concrete context of existing distortions in the trade regime as well as in a whole range of other economic activities. If the only distortion were in trade policy, trade reforms are likely to be unambiguously welfare increasing. But in assessing the impact of trade policy reforms, particularly in developing countries, it should be recognised that both market and nonmarket failures are pervasive. This is particularly so in the case of agriculture.

First, agricultural production is replete with examples of market failure, so that prices of inputs and outputs in agricultural markets do not fully reflect the social costs (including poverty) of a range of agricultural activities, producing effects such as soil and water depletion, various forms of pollution, deforestation, and over grazing. These externalities and "public bads" have economywide effects that are 
not limited to agriculture alone, but influence negatively other sectors in the economy. Second, agriculture faces a problem of government or "non-market failure", which can misdirect resource allocation through policy distortions and imperfections (Stiglitz, 1987; Panayotou, 1990; and Johnson, 1991). Further, it should be noted that sector specific policies may have unintended impacts on other sectors in the economy. A comprehensive study of the likely impacts of trade policy reforms since 1977 and changes of future international policy environment in line with GURAA, SAPTA, and SAFTA on the non-plantation agricultural sector and the effects of on-site and off-site cost of soil erosion has not been undertaken. Further, it is imperative to determine whether the trade policy liberalisation in nonplantation agriculture is a 'green policy device' for reducing agroenvironmental damages.

The purpose of this paper is to examine the likely effects of tariff policy liberalisation in line with the GATT/Uruguay Round Agreement on Agriculture (GURAA), the South Asian Preferential Trading Arrangement (SAPTA) and the South Asian Free Trade Area (SAFTA) on the performance of the non-plantation agricultural sector and the cost of land degradation-induced on-site and offsite effects in Sri Lanka. To this end, we intend to scrutinise the literature available on the subject and examine the possible impact of such a liberalising international policy environment on non-plantation agriculture in Sri Lanka. In the analysis, we focus on highland, midland and lowland non-plantation agricultural sectors.

The rest of the paper is organised as follows: future agricultural policy liberalisation in line with GURAA, SAPTA and SAFTA and present context of agricultural tariff policy liberalisation and import tariff structure on the non-plantation agricultural sectors in Sri Lanka is reviewed in section 2. Section 3 explains the basic features of the computable general equilibrium (CGE) model developed for the Sri Lankan economy. The likely macro, meso and micro effects (including agro-environmental effects) of tariff policy liberalisation as a green policy device in line with the GURAA, SAPTA and SAFTA are explained in section 4. Conclusions and policy implications are included in the final section.

\section{Trade Policy Liberalisation Under GURAA, SAPTA and SAFTA}

The major policy thrust of the international policy environment in line with GURAA, SAPTA and SAFTA is integration with the world 
economy in order to create international competitiveness for both manufacturing and agricultural products. The following sections review the changes in the national and international trade policy environment and their effects.

\section{Agricultural Trade Policy Liberalisation Under GATT/Uruguay Round -WTO}

The GATT/Uruguay Round negotiations were the turning point for developing countries in their integration into the global economy. However, in the GATT/Uruguay Round, most countries were in favour of formulating new rules for the world trading system, including market access offers in reducing tariff protection in manufacturing and agricultural products and trade in services (Martin and Winters, 1996) The GURAA was important for making a base for future liberalisation, particularly to strengthen the world economy and lead to more trade, investment, employment and income growth throughout the world.

The trade reform provisions of the GURAA - WTO include three major categories: market accesses, domestic support and export subsidies. Under the main category of market access, Sri Lanka has to convert virtually all non-tariff measures (NTMs) on agricultural imports into ad valorem or specific tariffs ${ }^{1}$. The effective tariffs are to be "bound" and should be reduced over a period of six years ${ }^{2}$. Tariffication is based on the actual difference between internal and external prices during the years 1986 to 1988. Further, under the GURAA, tariffied products are subject to 'minimum access' ${ }^{3}$ requirements, which are to be guaranteed where necessary through tariff rates.

1. The conversion of NTMs in the economy into tariffs is referred as "tariffication".

2. A binding tariff rate is the legally set ceiling (maximum) rate of tariff for the country. The actual tariff can be lower than the bound maximum rate, but it cannot go beyond the ceiling, unless the tariff rate is renegotiated with trading partners. The period for reduction of tariff rate has been extended for ten years for developing and less developed countries (Athukorala and Kelegama, 1996).

3. In line with the 'minimum access' condition, when imports of a product subject to tariffication are less than six per cent of domestic consumption requirement in the base period (1986-1988), the minimum access opportunities are to be provided. The minimum access condition is equivalent to three per cent of base period consumption in the first year, increasing to five per cent in six years. In the case where imports of tariffied products exceeded five per cent of consumption in the base period, countries have to maintain the access opportunity that prevailed in the base period. 
Some categories of imports can get "special treatment" exemptions from tariffication requirements. The present structure of subsidies in Sri Lankan agriculture are consistent with WTO domestic support provisions and further policy adjustments are not necessary (Athukorala and Kelegama, 1996).

A major challenge for the World Trade Organisation (WTO), at present, is to ensure that trade liberalisation does not lead to undesirable social and environmental consequences. There are provisions under the "Green Box" to provide direct assistance as 'safety nets' to avoid undue social consequences. Subsidies on targeted purposes are however not included as tradedistorting elements and are thus exempted from reduction of subsidy requirement specified under the
GURAA-WTO (Athukorala and Kelegama, 1996).

Sri Lanka has fixed the 'bound' rate of tariff on agricultural imports ${ }^{5}$ at a uniform rate of 50 per cent, in compliance with the GURAA's commitments (WTO, 1996). The bound level of tariff selected for the Sri Lankan economy is the lowest among the four South Asian WTO member countries ${ }^{6}$ and one of the lowest among all developing-country WTO members (Martin and Winters, 1996). The gazetted tariff rates $^{7}$ on all agricultural products in Sri Lanka are much lower than the bound rate announced. Hence the GURAA commitments are unlikely to significantly accelerate agricultural trade reforms in Sri Lanka. However, recent experience suggests that domestic consumer pressures may be effective in achieving faster reforms in this area.

4. There are three eligibility criteria for the 'special treatment', namely: (i) imports of the product concerned should have accounted for less than three per cent of corresponding domestic consumption in the base period (1986-1988); (ii) the designated product should not have benefited from any export subsidies since the beginning of the base period; and (iii) measures limiting domestic production should be applied to the pertinent primary agricultural product

5. The imported items include about 700 agricultural products, which contain meat, fish, milk, milk powder, fruits, vegetables, nuts, spices, coffee, seeds, sugar, maize, starches, oils and fats, cocoa, pastries, fruit juices and fruit preparations.

6. Bangladesh declared an uniform tariff rate of 200 per cent, whereas Pakistan maintained bound rates in the range of 100-150 per cent. India has announced high binding rates of 100, 150 and 300 per cent for most products coupled with zero or low (between 10-40 per cent) rates for a few products (Athukorala and Kelegama, 1996).

7. The gazetted 3 band tariff rates were further reduced between 10-25 per cent in the budget speech for the year 2000 . 


\section{Agricultural Trade Liberalisation Under the SAPTA and SAFTA}

The regional integration through trading blocs is established mainly to gain advantages in trade liberalisation in line with the process of harmonisation of intra-regional trade. However, in December 1995 SAARC member countries were able to formulate the SAPTA and SAFTA agreements $^{8}$ in order to promote regional trade integration ${ }^{9}$. The trade expansion leads to further stimulate investment in improved technology and trade related other activities and thereby generates more employment opportunities.

In particular, the SAPTA agreement is based on the principles of reciprocity, equity, and mutual advantage with the liberalisation of the following four components, namely: tariff; para-tariff; non-tariff; and direct trade measures (SAARC, 1995). In the two rounds of negotiations of SAPTA in 1995 and in 1996, SAARC member countries announced their tariff concessions in relation to non-plantation agricultural sectors (see Appendix Tables 1 and 2). Considering these changes in the SAARC regional policy environment, Sri Lanka needs to further liberalise the tariff structure in relation to the non-plantation agricultural sectors. The Indo-Sri Lanka trade agreement (FTA) ${ }^{10}$, which signed by Sri Lanka and India, is one step forward in regional trade liberalisation, before implementation of SAPTA and SAFTA within the SAARC. This is basically complementary to the proposed policy reforms explained above in line with GURAA.

\section{Agricultural Trade Policy Liberalisation in Sri Lanka}

Sri Lanka was one of the first among developing countries, to implement a far-reaching program of economic policy reforms unilaterally as early as 1977, mainly under the structural adjustment policy (SAP) packages. Economic policy reforms implemented in Sri Lanka included: reductions of protection provided to import-competing sectors; provision

8. In principle, SAPTA and SAFTA agreements will be effective by the year 2001. The main objective of SAPTA is to promote and sustain mutual trade and economic co-operation among the contracting states through the exchange of concessions.

9. The value of intra-SAARC trade constitutes 3 per cent of world trade and still there is an enormous trade potential through integration for trade expansion and trade diversion (Samaratunga and Jayasuriya, 1996).

10. In the budget speech for the year 2000, the President categorically emphasised the necessity of implementation of the Indo-Sri Lanka trade agreement immediately (Budget Speech, 2000). 
of incentives to export oriented sectors; changing exchange rate regimes; fiscal and monetary reforms; liberalisation of domestic factor and product markets from government intervention thus allowing free play of market forces; and privatisation of some government business enterprises (Gunawardana and Somaratne, 1999). The reform process has been continued with the changes in government in 1989, and 1994 at varying degrees. The main declared objective of trade policy reforms was to achieve international competitiveness for the Sri Lankan agricultural and manufacturing products. There has been a growing body of literature ${ }^{11}$, which focuses on the historical process of economic policy reforms in Sri Lanka and their effects.

The non-plantation (domestic) ${ }^{12}$ agricultural sector in Sri Lanka is concerned with the production and marketing of food crops and livestock products, mainly for domestic consumption (ie. nontradeables). In 1999, both plantation (including forestry) and non- plantation agriculture together contributed 16.4 per cent of GDP; and 20.6 per cent of the value of exports; (Central Bank of Sri Lanka, 1999) and 38.7 per cent of the employed labour force (Central Bank of Sri Lanka, 1996). The nonplantation agricultural sectors alone contributed about 13.2 per cent of GDP in 1999 (Central Bank of Sri Lanka, 1999). This sector also accounts for a sizeable proportion of area under cultivation in the country. For instance, in 1990, paddy and other food crops accounted for about 58 per cent of total cultivable land, while the plantation sector accounted for about 38 per cent and other crops 4 per cent (World Bank, 1990).

During the 1978 to 1983 period, the non-plantation agriculture was heavily protected (eg. high tariffs and extensive non-tariff measures licensing, quotas, and other regulations), particularly in relation to crops such as potatoes, onions and chillies. However, a policy of import liberalisation was followed, under which the non-plantation agriculture was exposed to import competition.

\footnotetext{
11. Particularly in relation to the macroeconomic effects (Rajapathirana, 1988; Cuthbertson and Athukorala, 1991; Athukorala and Jayasuriya, 1994; Laksman, 1994;), fiscal Impacts (Bandara, 1994), Plantation Agriculture (Gooneratne and Wesumperuma, 1984; Edwards, 1993); manufacturing industries (Athukorala, 1986; and 1994; Jayanthakumaran, 1991, Edwards, 1993), policy regimes and the non-plantation agriculture (Gunawardana and Somaratne, 1996 and 1999) and economywide effects (including agro-environmental effects) of policy liberalisation (Somaratne, 1998) .
} 
On the other hand, the domestic food crop sector, in particular the rice sector, received both trade protection and a range of input subsidies [ie. irrigated water, fertiliser, research and development (R\&D) and extension services]. In the 1994 regime, diversification of the crop mix towards commercial, agroindustrial and exportable crops (mainly vegetables, fruits and cut flowers) fisheries (ie. lobsters, shellfish, shrimps, prawns and other ornamental fish) was also on the policy agenda.

The previous analytical studies concentrate on specific sectors and issues. For instance Bhalla (1991) deals with the political economy and determination of agricultural prices, Edwards (1993) examines the extent of protectionism in relation to food crops and livestock products during 1985 to 1991, Gunawardana and Quilkey (1987) analyse the welfare effects of rice pricing policies and marketing policies during 1952 to 1984, Edirisinghe et al., (1992) and Somaratne and Wickramasinghe (1993) examine the efficiency and incentive structure in rice production in Sri Lanka, and Gunawardana and Somaratne (1999) investigate the impacts of different economic regimes on the performance of the non- plantation agricultural sector in Sri Lanka, during 1970 to 1997.

\section{Structure of Import Tariff and Incentives and Non-Plantation Agricultural Sectors}

Since 1977, import tariff protection provided to Sri Lankan agriculture has been gradually reduced in line with the liberalised trade and other agricultural reform policies, with the objective of increasing the international competitiveness of Sri Lankan agricultural products. Once the trade barriers relating to agriculture became an internationally prominent issue with GURAA, Sri Lanka's tariff and related protectionist policies were the subject of critical analysis. In this context, quantitative restrictions (QRs), import tariffs, export taxes, export subsidies and exchange controls were dismantled and other institutional and reform structures were undertaken which were conducive to economic growth in Sri Lanka. The Sri Lankan tariff structure $^{13}$ has been periodically reviewed since 1980, and successive changes toward a lowered tariff structure have been implemented (Ratnayake, 1993; Report of Presidential Tariff Commission on Tariff and Trade, 1994).

13. In 1977, most QRs were replaced by a six-band duty system for imports ranging from 0 per cent for essential consumer goods to 500 per cent tariff rates on luxury items. These rates were imposed even on agricultural sectors, considering various commodity specific tariff rates. 
The present rates of import tariff imposed on non-plantation agricultural crop sectors (Rice, Sugar, Potatoes, Red onions, B'onions, Greengram, Blackgram, Dried Chillies, Maize and Split lentils) range from 10 to 35 per cent (see Appendix Table 3). The 20 per cent tariff rate is applied for wheat and the 10 per cent tariff rate is claimed for condiments like coriander, cummin seed, and fennel seed. The tariff structures have distorted resource allocation both between plantation and nonplantation agricultural sectors and between agriculture and other sectors. Furthermore, tariff protection appears to have increased the cost of land degradation-induced on-site and off-site environmental damages. For example, a high rate of import tariff protection was given to potatoes, onions and chillies subsectors despite these crops being the most soil erosive crops (Somaratne, 1998).

The average effective protection coefficient (EPC) for the agricultural sector was 1.6, while that of the manufacturing sector was 1.8 , during the period 1988 to 1991 (Appendix Table 4). However, in 1992/93, whilst the EPC remained unchanged in agriculture, the EPC declined from 1.8 to 1.7 in the manufacturing sector. But in 1992/93, the EPC in the manufacturing sector continued to be higher than in the agricultural sector. In this context, the most highly protected sector in Sri Lankan agriculture is the non-plantation agricultural sector.

\section{A CGE Model for the Sri Lankan Economy}

A recent phenomenon in the economic modelling arena, is the development of a class of economywide computable general equilibrium (CGE) models, which are mainly employed to evaluate the likely economy-wide impacts of a wide range of policy issues. Basically these models provide an internally consistent economy-wide framework for policy analysis, in considering internal and/or external shocks to an economy on macro and micro economic variables.

There were four pioneering CGE models ${ }^{14}$ developed for the Sri Lankan economy. In Somaratne model (1998), the relationship between trade policy (ie. tariff)

14. The CGE models were developed by Bandara (1989), Center for International Economics (CIE) (1992), Herat (1994), Bandara et al., (1995), and Somaratne (1998) to evaluate the economywide likely impacts of various policy issues including external shocks, 'Dutch disease' type policies, technological change, and trade policy issues. All of these models are neo-classical, comparative static models, the structure of which is based on the ORANI model of the Australian economy (Dixon, et.al. 1982). 
reforms and the issues on of land degradation, including on-site externalities, (ie. land degradation- cost of land degradation and off-site induced off-site effects) was impacts of irrigated agriculture, considered. The CIE (1992) and hydro-power generation, flushing Somaratne $^{15}$ (1998) models used a cost of Kothmale reservoir, operation recent input-output database in and maintenance cost of highland taking into account economic and midland road network, and other liberalisation-induced structural changes in the Sri Lankan economy.

The production structure of the CGE model for Sri Lanka is presented schematically in Figure 1. In this analysis, the comparativestatic $\mathrm{CGE}^{16}$ model $^{17}$ developed by Somaratne (1998), which belongs to Johansen ${ }^{18}$ class, witch was linear variables, is adopted as the base for analysis, with further disaggregation of the model. Although modelling of all land degradation-induced effects is an extremely difficult task, efforts have been made to evaluate the policy-induced economywide effects cost of environmental damages (e.g. cost of health hazards and purification of water).

In this model, land mobility is allowed between crop industries within upland, midland and lowland regions. The relative price changes of products resulting from changes in economic policy framework influence the land use patterns in the economy, which in turn affects the sectoral rates of soil erosion. Changes in levels of soil erosion linked to changes in land use patterns in the upland and midland regions

15. The equation system of the CGE model was not included due to space limitations of the paper.

16. The CGE model for the Sri Lankan economy included 40 industries. In agriculture, tea sector was disaggreated into highland, midland and lowland tea sectors while the other agriculture sector was disaggregated into highland, midland and lowland other agriculture and upland potatoes. The model includes 14 agricultural industries in the upland, midland and lowland regions. Each industry produces a single commodity by using three primary factors: land, labour and capital.

17. The main data source used for the model is the input-output table developed by the Department of Census and Statistics in 1989, which was further updated and improved in 1991 by the CIE, incorporating the structural changes taking place in the economy, after the second wave of economic reforms in 1989. This input-output data base captures the production accounts in the economy, the share coefficients in sales, costs and revenues in current production, investment, household consumption, foreign trade, and margin industries (marketing value-added distribution etc.) are computed to implement the relevant CGE model

18. The advantage of the Johansen class models is the flexibility to address a range of comparativestatic problems involving changes in policies, prices, factor endowment and technologies. 
Figure 1: Schemaic presentation of the Sri Lankan CGE model.

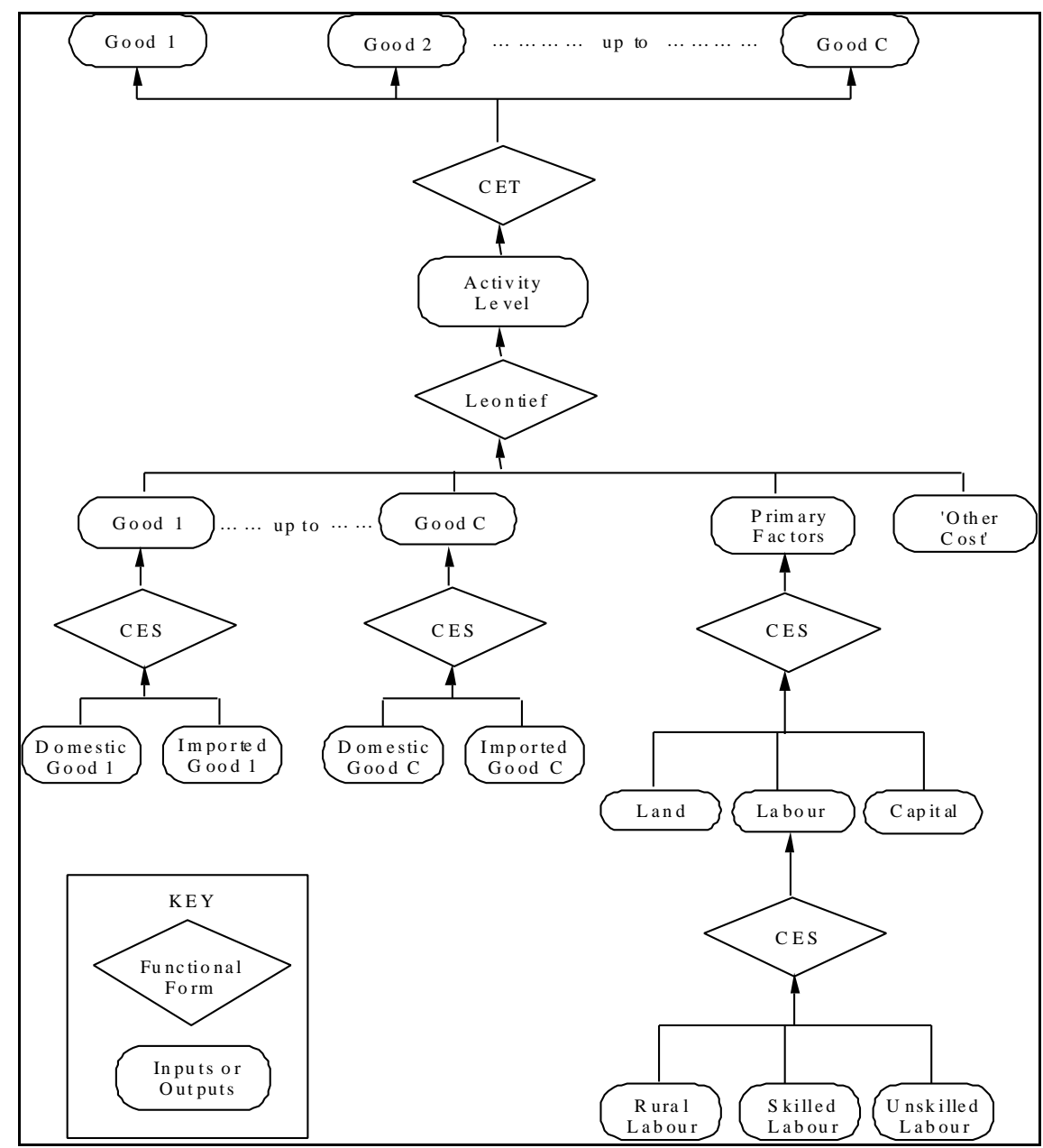



have both on-site and off-site consequences. The main off-site impact of land degradation is the reduction of the productivity of physical structures for the storage and delivery of water for irrigation and hydropower generation. An increase in sediment delivery rate to these water storage tanks in the lowland areas directly increases the costs in irrigated agriculture and hydropower generation. The on-site productivity impacts from soil erosion and the off-site impacts of reduction in irrigation capacity for crops and hydropower generation are modelled to estimate the value of depletion of natural capital in the Sri Lankan economy. For given quantities of sector-specific capital endowments, an increase in erosion levels in the upland and midland sectors reduces lowland sectors' output by reducing their effective specific factor endowment. The parameter measuring the relationship between changing land use and induced soil erosion in the upland and the loss of irrigation capacity in the lowland cannot be directly estimated due to a lack of secondary data. The off-site impact parameter ${ }^{19}$ used in the Bandara et al., (1995) model is adopted for the present analysis.
In all simulation experiments of tariff liberalisation, a model closure is employed in which real wages and balance of trade are fixed. Accordingly, shifts in labour demand are absorbed by quantity adjustments (endogenous labour supply), and aggregate net income changes appear as changes in real household consumption. In addition, the nominal rate of foreign exchange remains fixed, as a numereire of the model. Any movements in domestic price levels change the real exchange rate, which is defined as the ratio of an index of the border prices of tradable to an index of domestic prices. The small country assumption is employed and world prices of imports are treated as exogenous. In this analysis, it is assumed that real wages are fixed and allowed to determine endogenously the level of aggregate employment in the economy. The rate of soil erosion at both sectoral and for the economy as a whole is an endogenous variable in the model.

\section{Macro and Meso Economic Effects of Tariff Policy Liberalisation}

In this section, we present the empirical analysis of the effects of trade policy liberalisation in Sri Lanka in line with the above

19. The off-site impact parameter based on the Philippine experience, for measuring off-site damage in lowland agriculture and hydro-power generation was 0.1 , indicating that a 1 per cent increase in acreage of upland crop sectors reduces the lowland irrigated area and hydro-power generation by 0.1 per cent. 
mentioned broad policy liberalisation framework of GURAA, SAPTA, and SAFTA, based on recent studies conducted in relation to the nonplantation agricultural sectors in Sri Lanka. Particularly, as explained by Somaratne (1998), tariff liberalisation in regional nonplantation agricultural sectors (ie. upland midland and low land) was analysed, considering three policy scenarios, namely partial tariff reduction (ie. 50 per cent tariff reduction in non-plantation agricultural sectors), total removal of tariff in non-plantation agricultural sectors and across-the-board tariff reduction (ie. 50 per cent across-theboard tariff reduction in all import competing sectors). A comparative static Computable General Equilibrium (CGE) model $^{20}$ was developed to evaluate the likely economywide effects of tariff liberalisation in the non-plantation agricultural sectors in Sri Lanka.

\section{Macroeconomic Effects}

The projections of the macroeconomic effects of tariff liberalisation in line with GURAA, SAPTA, and SAFTA are presented in Table 1 based on Somaratne
(1998). The results show that tariff liberalisation is likely to lead to a higher real GDP. When the rate of tariff reduction in the non-plantation agricultural sectors increases, it increases the growth rate of real GDP, by stimulating output in the exportable agricultural and industrial manufacturing sectors. However, greater growth benefits can be secured with across-the-board tariff liberalisation in all import competing sectors, rather than sector specific tariff liberalisation.

Further, both partial and acrossthe-board tariff liberalisation increase the level of aggregate employment in the economy, reduce the aggregate price level, and thereby improve the aggregate real household consumption. Moreover, tariff liberalisation stimulates trade, leading to higher imports and exports and improves the balance of trade. At the same time, it also leads to an improvement in the government budget $^{21}$ along with partial and total tariff liberalisation in non-plantation agricultural sectors and across-theboard tariff reduction in all import competing sectors, through fiscal expansion particularly in the exportoriented product sectors (Table 1).

20. See Somaratne, (1998) for comprehensive details on the CGE model theory and its applications in relation to analysis conducted in non-plantation agricultural sectors in Sri Lanka.

21. Note that in the base model, there is a deficit in the government budget. 
Table 1. Projections of the effects of tariff reduction on macro variables in Sri Lanka (percentage changes)

\begin{tabular}{|c|c|c|c|}
\hline \multirow[t]{2}{*}{ Variable Description } & \multicolumn{3}{|c|}{ Tariff Reduction } \\
\hline & $\begin{array}{c}\text { Policy } 1 \\
*\end{array}$ & $\begin{array}{c}\text { Policy } 2 \\
* *\end{array}$ & $\begin{array}{c}\text { Policy } 3 \\
\#\end{array}$ \\
\hline A. Government Budget Position (Rs Million) $)^{22}$ & 110 & 218 & 5033 \\
\hline \multicolumn{4}{|l|}{ B. Household Consumption and Disposable Income } \\
\hline i. Aggregate nominal household consumption & -0.43 & -0.87 & -2.9 \\
\hline ii. Aggregate real household consumption & 0.04 & 0.09 & 1.2 \\
\hline iii. Nominal household disposable income & -0.44 & -0.87 & -4.1 \\
\hline \multicolumn{4}{|l|}{ C. Price Indices } \\
\hline i. GDP deflator & -0.46 & -0.93 & -5.1 \\
\hline ii. Consumer price index & -0.48 & -0.96 & -4.1 \\
\hline D. Aggregate Employment & 0.11 & 0.22 & 2.15 \\
\hline \multicolumn{4}{|l|}{ E. Gross Domestic Product } \\
\hline i. Nominal GDP & -0.44 & -0.87 & -4.14 \\
\hline ii. Real GDP & 0.03 & 0.06 & 0.98 \\
\hline$* \quad 50 \%$ tariff reduction in non-plantati & gricultura & sectors only & \\
\hline $100 \%$ tariff reduction in non-planta & 1 agricultur & sectors on & \\
\hline $50 \%$ across-the-board tariff reductio & & & \\
\hline Somaratne, (1998) & & & \\
\hline
\end{tabular}

Meso Economic Effects

\section{Sectoral Production and Exports}

Tariff liberalisation (either sector specific or across-the-board) creates direct impacts on import competing industries and indirect impacts on other export (or non-import competing) industries. In the tariff reduction policy experiments in line with market integration along with changes in international policy environment, the effects on individual commodities depend on their trade orientation - output increases in export-oriented products and declines in import competing products. As illustrated in Table 2, all non-plantation crop sectors are vulnerable to increased competition, while exportable plantation and agrobased industries tend to benefit from liberalisation. In particular, the lowgrown tea sector expands at the expense of non-plantation crops.

22. Note that in the base model there is a deficit in the government budget. However, partial and total tariff liberalisation in non-plantation agricultural sectors and across-the-board tariff reduction in all other import competing sectors assists to reduce the budget deficit. 
Exportable products, such as other manufacturing and agro-based products (including processed tea), are also stimulated.
In summary tariff liberalisation fosters economic growth and improves most macro economic indicators.

Table 2. Projections of the effects of tariff reduction on production, and exports of agricultural crops (percentage changes)

\begin{tabular}{|c|c|c|c|c|}
\hline \multirow[t]{2}{*}{ Crop Sector } & \multirow{2}{*}{$\begin{array}{l}\text { Classification } \\
(\mathrm{X} / \mathrm{M} / \mathrm{N}) \# \#\end{array}$} & \multicolumn{3}{|c|}{ Tariff: Reduction } \\
\hline & & Policy 1* & Policy $2 * *$ & Policy 3\# \\
\hline \multicolumn{5}{|l|}{ Production } \\
\hline \multicolumn{5}{|l|}{$\overline{\text { Plantation Crops }}$} \\
\hline Tea - Highgrown & $\mathrm{N}$ & 0.34 & 0.68 & 2.93 \\
\hline Tea - Midgrown & $\mathrm{N}$ & 0.29 & 0.57 & 2.80 \\
\hline Tea - Lowgrown & $\mathrm{N}$ & 0.68 & 1.36 & 4.63 \\
\hline Rubber & $X$ & 0.36 & 0.71 & 3.42 \\
\hline Coconut & $\mathrm{X}$ & 0.15 & 0.30 & 1.79 \\
\hline Export Agriculture & $X$ & 0.28 & 0.56 & 2.30 \\
\hline Forestry & $\mathrm{N}$ & 0.04 & 0.07 & 0.58 \\
\hline \multicolumn{5}{|l|}{ Non-Plantation Crops } \\
\hline Other Agriculture - Highland & M & -0.67 & -1.34 & -0.56 \\
\hline Other Agriculture - Midland & M & -0.68 & -1.37 & -0.59 \\
\hline Other Agriculture - Lowland & M & -0.59 & -1.19 & -0.16 \\
\hline Potatoes - Highland & M & -1.18 & -2.36 & -1.07 \\
\hline \multicolumn{5}{|l|}{ Agro-Based Products } \\
\hline$\overline{\text { Coconut Processing }}$ & $\mathrm{X}$ & 0.57 & 1.15 & 5.89 \\
\hline Rice Processing & M & 1.80 & 3.60 & 2.70 \\
\hline \multicolumn{5}{|l|}{ Exports } \\
\hline$\overline{\text { Processed Tea }}$ & $\mathrm{X}$ & 0.53 & 1.06 & 4.15 \\
\hline$* \quad 50 \%$ tariff reduction & non-plantation a & gricultural & ectors only. & \\
\hline $100 \%$ tariff reduction & non-plantation & agricultura & sectors only. & \\
\hline $50 \%$ across-the-boar & ariff reduction. & & & \\
\hline \#\# $\quad \mathrm{X}$ : Exportable; M: In & ortable; N: Non- & radable & & \\
\hline
\end{tabular}




\section{Changes in Factor Demand and Rate of Land Degradation}

Tariff liberalisation encourages a shift of lands in an environmentally friendly direction in Sri Lanka. It increases land devoted to low soil erosive plantation crops like tea in high and mid elevations, and reduces erosive non-plantation crops (eg. potatoes in highland regions) (Table 3). Consequently, it substantially reduces the sectoral level of soil erosion in non-plantation sectors as well as the level of aggregate cultivation of highly erosive crops in the economy (see Table 4).

Table 3. Projections of the effects of tariff reduction on factor demand (percentage changes)

\begin{tabular}{|c|c|c|c|}
\hline \multirow[t]{2}{*}{ Crop Sector } & \multicolumn{3}{|c|}{ Rate of Tariff Reduction } \\
\hline & Policy $1 *$ & Policy $2 * *$ & Policy $3 \#$ \\
\hline \multicolumn{4}{|l|}{ A. Labour Demand } \\
\hline \multicolumn{4}{|l|}{$\overline{\text { Plantation Crops }}$} \\
\hline Tea - Highgrown & 0.34 & 0.67 & 3.55 \\
\hline Tea - Midgrown & 0.28 & 0.57 & 3.42 \\
\hline Tea - Lowgrown & 0.68 & 1.35 & 5.25 \\
\hline Rubber & 0.50 & 1.01 & 4.85 \\
\hline Coconut & 0.22 & 0.45 & 2.68 \\
\hline Export Agriculture & 0.88 & 1.75 & 7.15 \\
\hline \multicolumn{4}{|l|}{ Non-Plantation Crops } \\
\hline Other Agriculture - Highland & -1.51 & -3.01 & 7.52 \\
\hline Other Agriculture - Midland & -1.43 & -2.86 & 7.70 \\
\hline Other Agriculture - Lowland & -2.01 & -4.01 & 5.04 \\
\hline Potatoes - Highland & -2.14 & -4.29 & 6.88 \\
\hline \multicolumn{4}{|l|}{ B. Land Use } \\
\hline \multicolumn{4}{|l|}{ Plantation Crops } \\
\hline Tea - Highgrown & 0.46 & 0.92 & 1.98 \\
\hline Tea - Midgrown & 0.39 & 0.78 & 1.81 \\
\hline Tea - Lowgrown & 0.92 & 1.83 & 4.25 \\
\hline \multicolumn{4}{|l|}{ Non-Plantation Crops } \\
\hline Other Agriculture - Highland & -0.65 & -1.30 & -3.11 \\
\hline Other Agriculture - Midland & -0.69 & -1.39 & -3.22 \\
\hline Other Agriculture - Lowland & -0.38 & -0.75 & -1.74 \\
\hline Potatoes - Highland & -1.29 & -2.58 & -3.75 \\
\hline $\begin{array}{l}50 \% \text { tariff reduction } \\
100 \% \text { tariff reductic }\end{array}$ & i-planta & $\begin{array}{l}\text { icultural s } \\
\text { gricultural }\end{array}$ & $\begin{array}{l}\text { only. } \\
\text { s only. }\end{array}$ \\
\hline
\end{tabular}


109

Table 4. Projections of tariff reduction-induced effects on rate of soil erosion (percentage changes)

\begin{tabular}{lccc}
\hline \multicolumn{1}{c}{ Crop Sector } & \multicolumn{3}{c}{ Tariff Reduction } \\
& Policy 1 $^{*}$ & Policy $2^{* *}$ & Policy 3 \# \\
\hline Plantation Crops & & & \\
Tea-Highgrown & 0.46 & 0.92 & 1.98 \\
Tea-midgrown & 0.39 & 0.78 & 1.81 \\
& & & \\
Non-Plantation Crops & & & \\
Other Agriculture - Highland & -0.65 & -1.30 & -3.11 \\
Other Agriculture - Midland & -0.69 & -1.39 & -3.22 \\
Potatoes - Highland & -1.29 & -2.58 & -3.75 \\
Aggregate Soil Erosion & -0.25 & -0.50 & -1.13 \\
\hline
\end{tabular}

* $\quad 50 \%$ tariff reduction in non-plantation agricultural sectors only.

** $\quad 100 \%$ tariff reduction in non-plantation agricultural sectors only.

\# $\quad 50 \%$ across-the-board tariff reduction.

Source: Somaratne, (1998).

\section{The Cost of Land Degradation}

A rigorous estimate of the overall cost of land degradation ${ }^{24}$ in Sri Lanka is not available. This is not surprising; the valuation of all land degradation-induced on-site and offsite effects is not an easy task. Environmental damages implicitly impose costs on economies that are often not reflected in market prices. The continued soil loss (ie. depletion of natural capital) might undermine future generation of income, and represents an important barrier to economic development. Valuation of the environment through comparison of environmental benefits with costs of environmental protection assists policy makers to make rational decisions. In making choices about environmental priorities, policies, and standards, government explicitly or implicitly places values on damages. Even though environmental benefits and costs are often difficult to estimate, it is advisable to make an effort to measure them and assess the tradeoffs and risks.

24. Data used to estimate the land degradation-induced on-site and off-site costs are not included in this paper due to space limitations. The data are available on request from the author. 
The estimation of all the on-site and off-site impacts ${ }^{25}$ of land degradation are extremely complex, along with the prevailing technical and other information problems. However, it is imperative to make an effort to estimate the cost of possible and quantifiable impacts to aid in an environmentally friendly - 'green' policy making process. An essential step in determining what should be done about environmental damage, is to value it and compare it with the cost of preventing such damages. Measurements are necessary, since trade-offs are unavoidable. In the case of setting priorities for policy formulation, valuing the environmental damage is imperative.

In this context, based on Somaratne $^{26}$ (1998) estimates, the range of land degradation-induced on-site cost per hectare per year is estimated to be Rs. 3529 to Rs. 5068 . The cost per ton of soil loss per year is Rs. 141 to Rs. 203. The net aggregate on-site and off-site land degradation cost per year ranged between Rs.Million 2776 to Rs. 3889 per year (see Appendix Table 5), which as a percentage of total GDP ranged between 0.72 to 1.0 and as a percentage of total agriculture's share of GDP ranged between 2.78 to 3.89 (Appendix Table 5). The total on-site and off-site cost of land degradation for non-plantation crops is higher than for plantation crops under both methods of evaluation (see Appendix Table 5). The land degradation-induced on-site cost as a percentage of GDP in Sri Lanka is on par with the other selected tropical developing countries. Particularly, on-site cost of land degradation in Costa Rica, Malawi, Mali, and Mexico is ranging between 0.5 to 1.5 per cent of GDP (World Bank, 1992).

The tariff reduction-induced onsite and off-site net environmental benefits ranged between Rs. Million 9.89 to Rs. Million 43.33 per year, depending on the policy shocks (Appendix Table 6). As a single policy device, tariff liberalisation in the non-plantation agricultural sector, and the across-the-board tariff reduction creates positive

25. See Tobey and Smets, (1996), and Somaratne (1998, and 1999) for a detailed discussion on the main categories of agricultural environmental costs including land degradation and its associated on-site cost (ie. value of loss of on-site production) and off-site agro- environmental costs (ie. value of loss of hydropower generation, and production of irrigated agriculture; flushing cost of Kothmale reservoir; O\&M cost of upland road network and other off-site costs).

26. Due to space limitations, comprehensive details on methods of measuring the land degradationinduced on-site and off-site environmental costs in Sri Lanka are not included here. See Somaratne (1999) for data and details on methods of environmental valuation. 
environmental benefits through saving of natural capital for future use to maintain sustainability. In this context tariff liberalisation in the non-plantation agricultural sector can be categorised as one of the 'green trade policy' devices, which assists to gain 'win-win solutions'.

\section{Concluding Remarks and Policy Implications}

This paper has examined the issue of tariff policy liberalisation in line with proposed GURAA, SAPTA, and SAFTA in a general equilibrium framework, focusing on likely macro and meso-economic effects and policy-induced on-site and off-site effects of land degradation in Sri Lanka. Sri Lanka has been implementing major policy reform programmes, including trade policy liberalisation in the nonplantation agricultural sectors in Sri Lanka, anticipating expected future changes in the international policy environment, such as SAPTA and SAFTA within the SAARC framework and the Indo-Sri Lanka trade agreement (FTA).

Three policy experiments including partial (ie. sectoral) and across-the-board tariff reduction were carried out using a CGE model to examine the likely impacts of proposed policy changes within the SAPTA and FTA policy framework.
The model outcomes generated information on a range of conventional macroeconomic performance indicators. In this context, our results provide a reliable basis for drawing some robust conclusions about the likely impact of future tariff liberalisation as a 'green policy' device, and its macroeconomic effects, mesoeconomic (or sectoral) consequences and land degradation-induced on-site and of-site effects, particularly in the non-plantation agriculture.

Based on policy experiments, it showed conclusively that tariff policy liberalisation as a 'green policy device' in the specific context of Sri Lanka would create positive economic and environmental benefits for the economy. Trade reforms reduce policy distortions which tax less soil erosive crops like tea, rubber and coconut and management practices in the upland and midland regions and turn incentives away from more erosive crops (ie. nonplantation crops) and cropping systems. There is a clear need for complementary microeconomic and environmental policies, which would enhance incentives for productivity and marketing improvements to minimise the policy-induced diseconomies at the farm level.

In this context, further liberalisation of tariff policy and the 
structure in the non-plantation agriculture in Sri Lanka is economically viable as a policy of 'greening' the Sri Lankan trade. There is a possibility of gaining a 'win-win' solution by enhancing the rate of economic growth and reducing the cost of land degradation-induced externalities. Considering these factors, if policy distortions (ie. tariff protection) in non-plantation agricultural sectors continue further, producer benefits in the short-run will be maintained at the enormous expense of long-run on-site production losses and off-site cost of externalities as well as other diseconomies in the economy.

The Government sector also has a role to play in facilitating the formulation of micro, complementary incentive policies to shift the land use pattern from high soil erosive non-plantation crops to internationally tradable, low soilerosive perennial crops like tea, rubber, and spices. Moreover, the role of the private sector has to be redefined in line with the changes in the national and international policy environment (ie. 'globalisation'). Incentive packages should be formulated for targeted nonplantation agricultural crop sectors to encourage investment, considering similar incentive packages implemented in the manufacturing sector (ie. BOI incentive packages).
In this respect, it is advisable to identify the advantageous exportable crops and products (ie. spices, horticultural products - 'bell pepper', ornamental fish, cut flowers, and other products - arecanut) within non-plantation agriculture and implement the strategy of regional specialisation. The provision of technological know-how, and planting materials and adoption of improved farm management practices should be encouraged even through the private sector.

Sri Lanka has the ability to formulate complementary incentive packages either through 'safty nets' or under the declared provisions of the 'Green Box' of GURAA to safe guard the interests of both farmers and consumers.

The possible complementary micro level policy options to enhance the growth of non-plantation agricultural sector would be through: (a) Vertical and horizontal integration: encouragement of private sector investors for value adding activities and crop diversification for exportable and targeted non-plantation crops through regional specialisation and attractive incentive packages;

(b) Rural land market: shifting lands from high soil erosive annual non-plantation (ie. food) crops to 
low soil erosive perennial crops through creation of a rural land market by allowing free mobility of lands; and

(c) Rural capital market: creation of a rural capital market by removing existing imperfections;

These micro level complementary policy options would enhance the growth of the nonplantation sector and move in the right direction through minimising the agro-environmental damages (ie. land degradation) in the long run.

Further, Sri Lanka as a small open economy, has the ability to gain benefits from expected policy liberalisation under GURAA, SAPTA, SAFTA, and globalisation. The potential benefits through integrating Sri Lanka into the world economy through market opportunities for agricultural and manufacturing products would be: improved and conducive environment for investment in technological development and advancement, and gains from expansion of exports of tradable agricultural and manufacturing products.

\section{Acknowledgement}

The author wishes to thank Dr. Sisira Jayasuriya, and Prof. A.H. Chisholm, School of Business, La
Trobe University, Bundoora, Melbourne, Australia for their suggestions and comments for the earlier version of this paper.

\section{References}

Athukorala, P. (1986). The Impact of 1977 Policy Reforms on Domestic Industry. Upanathi: Journal of Sri Lanka Association of Economists, 1: 69-106.

Athukorala, P. (1994). Economic Liberalization and Industrial Restructuring in Sri Lanka. Paper Presented at the International Conference on Economic Liberalisation of South Asia, Australian National University, Canberra.

Athukorala, P. and S. Jayasuriya (1994). Macroeconomic Policies, Crises and Growth in Sri Lanka. 1969-90. World Bank, Washington, D.C.

Athukorala, P. and S. Kelegama (1996). Agricultural Trade Liberalisation in the Uruguay Round: Implications for Sri Lankan Agriculture. Paper Presented at the World Bank/FAO, South Asia, WTO Seminar, Kathmandu, Nepal. 
Bandara, J.S., I. Coxhead, A.H. Chisholm, A. Ekanayake and S. Jayasuriya (1995). Economic Reforms and the Environment in Sri Lanka. Discussion Paper, 27/95, School of Agriculture, La Trobe University, Australia.

Bandara, J.S. (1989). A Multi Sectoral General Equilibrium Model of the Sri Lankan Economy with an Application to the Analysis of the Effects of External Shocks. Unpublished $\mathrm{PhD}$ Thesis, School of Economics, La Trobe University, Melbourne.

Bandara, J.S. (1994). The Fiscal Impact of Trade Liberalization in Sri Lanka. Paper Presented to the International Conference on Economic Liberalisation of South Asia, Australian National University, Canberra.

Bhalla, S. (1991). Sri Lanka. In A. Krueger, M. Schiff and A. Valdes (eds.), The Political Economy of Agricultural Pricing Policy. 2, Asia, Baltimore: Johns Hopkins University Press (for the World Bank).

Central Bank of Sri Lanka (1996). Annual Report. Central Bank of Sri Lanka, Colombo, Sri Lanka.
Central Bank of Sri Lanka (1999). Annual Report. Central Bank of Sri Lanka, Colombo, Sri Lanka.

Center for International Economics CIE (1992). The Composition and Level of Effective Taxes for Exporting and Import Competing Production in Sri Lanka. Centre for International Economics, Canberra.

Cuthbertson, S. and P. Athukorala (1991). Sri Lanka. In, A.M. Choksi and D. Papageorgiou. (eds.), Economic Liberalisation in Developing Countries. Oxford: Blackwell.

Dixon, P.B., B.R. Parmenter, J. Sutton and D.P. Vincent (1982). ORANI: A Multi Sectoral Model of the Australian Economy. Amsterdam, North-Holland.

Edirisinghe, N., F. Aberatne, W.G. Somaratne, I. Tudawe and P. Wickramarachchi (1991). Efficiency and Policy Incentives in Rice Production in Sri Lanka. ARTI, in Collaboration with IFPRI Washington DC, USA and Colombo, Sri Lanka.

Edwards, C. (1993). A Report on Protectionism and Trade Policy in Manufacturing and 
Agriculture in Sri Lanka. Institute of Policy Studies, Colombo, Sri Lanka.

GATT (1994). The Results of the Uruguay Round of Multilateral Trade Negotiations. The Legal Text, GATT Secretariat, Centre William Rappard, Rue de Lausanne 154, CH - 1211, Geneva, Switzerland.

Gooneratne, W. and D. Wesumperuma (1984). Plantation Agriculture. In, W. Gooneratne and D. Wesumperuma (eds.), Sri Lanka: Issues in Employment and Development, ILO, ARTEP, Bangkok.

Gunawardana P.J. and W.G. Somaratne (1996). Economic Reforms Since 1977 and Their Impact on Domestic Agriculture in Sri Lanka. Paper Presented to the 25th Conference of Economists, Australian National University, Canberra.

Gunawardana P.J. and W.G. Somaratne (1999). Economic Policy Regimes and NonPlantation Agriculture in Sri Lanka Since 1970. In, W.D. Lakshman and C.A. Tisdell (eds.), Facets of Development of Sri Lanka Since Independence: Socio-Political,
Economic, Scientific and Cultural. Economics Conference Monograph No: 6, Department of Economics, University of Queensland, Brisbane, Australia.

Gunawardana, P.J. and J.J. Quilkey (1987). Pricing and Marketing Policies in the Rice Sector of Sri Lanka: History and Impact, Upanathi: Journal of Sri Lanka Association of Economists, 1: 227-279.

Herat, P.W.R.B.A.U. (1994). An Investigation of the Impact of Some Recent External and Internal Shocks on the Economy of Sri Lanka. Central Bank of Sri Lanka, Colombo, Sri Lanka.

Jayanthakumaran, K. (1991). Trade Reforms and Industrial Performance of Sri Lanka (1977-1990): A Survey. Upanathi: Journal of Sri Lanka Association of Economists, 6: 133-147.

Johnson, D.G. (1991). World Agriculture in Disarray. $2^{\text {nd }}$ Edition, London: Macmillan.

Lakshman, W.D. (1994). Structural Adjustment Policies in Sri Lanka: Imbalances, Structural Disarticulation and 
Sustainability. Paper Presented to the International Conference on Economic Liberalisation of South Asia, Australian National University, Canberra.

Martin Will and L.A. Winters (1996). The Uruguay Round: A Milestone for the Developing Countries. In, W. Martin and L.A. Winters (eds.), Cambridge: Cambridge University Press.

Panayotou, T. (1990). The Economics of Environmental Degradation: Problems Causes and Responses. Development Discussion Paper No. 335, A CARE Project Report, Harvard University, Harvard Institute for International Development, USA.

Presidential Commission on Tariffs and Trade (PCTT) (1994). Report of the Presidential Commission on Tariffs and Trade, Colombo, Sri Lanka.

Rajapathirana, S. (1988). Foreign Trade and Economic Development: The Case of Sri Lanka. World Development, 16: 1143-1157.

Ratnayake, R. (1993). Political Economy of Tariff Reforms in Developing Countries: Sri
Lankan Experience. Working Papers in Economics, No 113, University of Aucland, Wellingon.

SAARC (1995). Agreement on SAARC Preferential Trading Arrangement - SAPTA, SAARC Secretariat, Kathmandu.

Samaratunga, R.H.S. and S. Jayasuriya (1996). Regional Economic Integration, Trade and Investment: South Asia and APEC. Paper Presented at the Conference of Economists, Australian National University, Canberra.

Somaratne, W.G. (1998). Policy Reforms and the Environment: General Equilibrium Analysis of Land Degradation in Sri Lanka. Unpublished $\mathrm{PhD}$ Thesis, School of Business, La Trobe University, Bundoora, Australia.

Somaratne, W.G. (1999). The Costs of Land Degradation in Sri Lanka. Paper Presented to the Fifth Annual Symposium on Forestry and Environment Challenges in Natural Resource Conservation in the $21^{\text {st }}$ Century, Organised by the Department of Forestry and Environmental Science, 


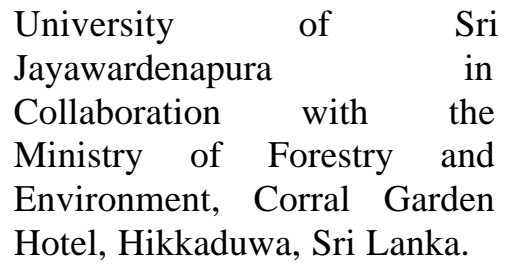

Somaratne, W.G. and W. Wickramasinghe (1993). Efficiency in Rice Production in Sri Lanka. Paper Presented at the Symposium on Policy Issues in Agriculture, Agrarian Research and Training Institute, Colombo, Sri Lanka.

Stiglitz, J.E. (1987). Some Theoretical Aspects of Agricultural Policies, World Bank Research Observer, 2 (1): 43-60.

Tobey, J.A. and H. Smets (1996). The Polluter-Pays Principle in the Context of Agriculture and the Environment, The World Economy, 19(1): 63-87.
World Bank (1990). Sri Lanka Sector Study and Programming Mission. Final Report, Washington, D.C.

World Bank (1992). Development and the Environment, World Development Report-1992, New York: Oxford University Press, Inc.

World Bank (1995). Sri Lanka: NonPlantation Crop Sector Policy Alternatives. Working Papers 17, Agriculture and Natural Resource Division, South Asia Region, The World Bank, Washington D.C..

World Trade Organization (WTO) (1996). Trade Policy Review Body - Sri Lanka; Report by the Secretariat - Summary and Observations, World Trade Organisation, Geneva. 
Appendix Table 1: $\quad$ Tariff concessions granted by Sri Lanka under the $1^{\text {st }}$ round of negotiations in the SAPTA agreement

\begin{tabular}{|c|c|c|c|c|c|}
\hline H.S.Code & Description & $\begin{array}{l}\text { Tariff } \\
\text { Rate (\%) }\end{array}$ & $\begin{array}{l}\text { Extent } \\
\text { Concession } \\
\text { For non- } \\
\text { LDCs }\end{array}$ & $\begin{array}{l}\text { of } \quad \text { Tariff } \\
(\%) \\
\text { For LDCs }\end{array}$ & $\begin{array}{l}\text { Remar } \\
\text { ks }\end{array}$ \\
\hline 0805.10 & $\begin{array}{l}\text { Orange } \\
\text { (SAARC) 20\% }\end{array}$ & 35 & \multirow{6}{*}{$\begin{array}{l}10 \% \text { of } \\
\text { tariff rate }\end{array}$} & $\begin{array}{l}15 \% \text { of } \\
\text { SAARC rate }\end{array}$ & \\
\hline 0808.10 & $\begin{array}{l}\text { Apples SAARC } \\
20 \%\end{array}$ & 35 & & $\begin{array}{l}15 \% \text { of } \\
\text { SAARC rate }\end{array}$ & \\
\hline 0909.20 & $\begin{array}{l}\text { Seeds of } \\
\text { Coriander }\end{array}$ & 10 & & & \\
\hline 0910.10 & Dried Ginger & 35 & & $\begin{array}{l}10 \% \text { of tariff } \\
\text { rate }\end{array}$ & \\
\hline 2006 & & & & $15 \%$ of tariff & \\
\hline $\begin{array}{l}2007 \\
2008\end{array}$ & Processed Fruits & 35 & & rate & \\
\hline
\end{tabular}

Appendix Table 2: $\quad$ Tariff concessions granted by Sri Lanka under the $2^{\text {nd }}$ round of negotiations in the SAPTA agreement

\begin{tabular}{|c|c|c|c|c|c|}
\hline \multirow[t]{2}{*}{ H.S.Code } & \multirow[t]{2}{*}{ Description } & \multirow{2}{*}{$\begin{array}{l}\text { Tariff } \\
\text { Rate } \\
(\%)\end{array}$} & \multicolumn{2}{|c|}{$\begin{array}{l}\text { Extent of Tariff } \\
\text { Concession }(\%)\end{array}$} & \multirow{2}{*}{$\begin{array}{l}\text { Any Special } \\
\text { NTBs with } \\
\text { Particular } \\
\text { reference to } \\
\text { QBs }\end{array}$} \\
\hline & & & $\begin{array}{c}\text { For } \\
\text { non- } \\
\text { LDCs }\end{array}$ & For LDCs & \\
\hline 0713.40 & Lentils & 35 & - & 20 & Nil \\
\hline 0805.20 & $\begin{array}{lr}\text { Mandarins } & \text { (including } \\
\text { tangerines \& } & \text { statusumas) } \\
\text { clementines, } & \text { wilkings } \\
\text { and similar citrus hybrids }\end{array}$ & 35 & - & 60 & Nil \\
\hline 0808.10 & Apples & 35 & - & 60 & Nil \\
\hline
\end{tabular}


Appendix Table 3: Rates of import tariff imposed on selected nonplantation agricultural crop sectors in Sri Lanka (1986/88 - 1998).

\begin{tabular}{|c|c|c|c|c|}
\hline \multirow[t]{2}{*}{ Products } & \multicolumn{4}{|c|}{ Tariff Rate (\%) } \\
\hline & $1986 / 88$ & 1994 & 1996 & 1998 \\
\hline Potatoes & 100 & $35 \%$ or Rs. 12.00 per kg & 35 & 35 \\
\hline Red Onions & 5 & $35 \%$ or Rs. 9.00 per $\mathrm{kg}$ & 35 & 35 \\
\hline B’Onions & 5 & $35 \%$ or Rs. 9.00 per $\mathrm{kg}$ & 35 & 35 \\
\hline Greengram (Moong) & 5 & $35 \%$ or Rs. 10.00 per kg & 35 & 35 \\
\hline Blackgram (Oorid) & 5 & $35 \%$ or Rs. 10.00 per kg & 35 & 35 \\
\hline Split Lentiles & 5 & $45 \%$ or Rs. 12.00 per kg & 35 & 35 \\
\hline Other & 5 & $35 \%$ or Rs. 12.00 per kg & 35 & 35 \\
\hline Dried Chillies & 5 & $35 \%$ or Rs. 20.00 per kg & 35 & 35 \\
\hline Other & - & $35 \%$ or Rs. 10.00 per kg & & \\
\hline Maize & 5 & $45 \%$ & 35 & 35 \\
\hline Rice & 25 & $35 \%$ or Rs. 7.00 per $\mathrm{kg}$ & 35 & 35 \\
\hline Cane Sugar & & $35 \%$ or Rs. 6.50 per $\mathrm{kg}$ & 35 & 35 \\
\hline Beet Sugar & & $35 \%$ or Rs. 6.50 per $\mathrm{kg}$ & & \\
\hline Wheat & 25 & N/A & 20 & 20 \\
\hline Ginger & 60 & N/A & 35 & 35 \\
\hline Turmeric & 60 & N/A & 35 & 35 \\
\hline Saffron & 60 & N/A & 35 & 35 \\
\hline Seeds of anise & 5 & N/A & 35 & 35 \\
\hline Coriander & 5 & N/A & 10 & 10 \\
\hline Cummin seed & 5 & N/A & 10 & 10 \\
\hline Fennel seed & 5 & N/A & 10 & 10 \\
\hline
\end{tabular}

Source: Department of Customs, Sri Lanka (for 1986/88; 1996; 1998).

Report of the Presidential Commission on Tariffs and Trade - 1994, (for 1994);

N/A: Not Available. 
Appendix Table 4: Structure of incentives for agricultural commodities in Sri Lanka

\begin{tabular}{|c|c|c|c|c|c|}
\hline \multirow[t]{2}{*}{ Sector } & \multicolumn{2}{|c|}{$1988-1991$} & \multicolumn{3}{|c|}{$1992-1993$} \\
\hline & NPC & $\mathrm{EPC}$ & $\mathrm{NPC}$ & $\mathrm{EPC}$ & $\begin{array}{l}\text { ESC\# } \\
(1993)\end{array}$ \\
\hline \multicolumn{6}{|l|}{ A. Import Competing } \\
\hline Agriculture & - & - & $(1.33)$ & $(1.53)^{*}$ & 1.68 \\
\hline Rice & 1.2 & 1.5 & 1.3 & 1.5 & 1.56 \\
\hline \multirow[t]{2}{*}{ Other Agriculture } & 2.0 & 2.8 & 2.0 & $(1.36)$ & 1.79 \\
\hline & - & - & $(1.5)$ & 2.8 & - \\
\hline Chillies & - & - & (1.6) & - & - \\
\hline Potatoes & - & - & $(2.4)$ & - & - \\
\hline B'onion & - & - & $(1.2)$ & - & - \\
\hline Lentils (1990-1993) & & & & - & \\
\hline Other Food Items & 1.3 & 1.6 & 1.4 & & - \\
\hline Sugar & 1.0 & 1.0 & 1.0 & 1.7 & - \\
\hline Milk & 1.1 & 1.8 & 1.3 & 1.0 & - \\
\hline White flour/bread & & & & 1.9 & \\
\hline \multicolumn{6}{|l|}{ B. Export Oriented } \\
\hline Agriculture & - & - & - & $(1.02)$ & 1.06 \\
\hline Plantation Agriculture & - & - & - & $(1.0)$ & 1.03 \\
\hline Tea and Rubber & 0.8 & 0.6 & 1.0 & 1.0 & 1.04 \\
\hline Coconut & 1.4 & 1.6 & 1.2 & 1.4 & 1.02 \\
\hline C. Agriculture-Average & 1.3 & 1.6 & 1.3 & $1.6(1.2$ & 1.32 \\
\hline $\begin{array}{l}\text { D. Manufacturing } \\
\text { Import Competing }\end{array}$ & 1.4 & 1.8 & 1.3 & $1.7(1.3$ & - \\
\hline Manufacturing & - & - & - & $(1.7)$ & - \\
\hline Export-Oriented & & & & & \\
\hline Manufacturing & - & - & - & $(1.0)$ & - \\
\hline
\end{tabular}

NPC: $\quad$ Nominal Protection Coefficient - the ratio of domestic price over boarder equivalent (world) price;

EPC: $\quad$ Effective Protection Coefficient - the ratio of value added under existing trade policy intervention to value added at border price;

ESC: $\quad$ Effective Subsidy Coefficient - EPC adjusted for net subsidies on non-traded inputs;

* $\quad$ Figures in the parenthesis are based on the World Bank (1995) estimates;

\# $\quad$ All figures of ESC are based on World Bank (1995) Estimates;

Source: Report of the Presidential Commission on Tariff and Trade, 1994; Edwards (1993); and World Bank (1995). 
Appendix Table 5: $\quad$ Land degradation-induced on-site and off-site environmental cost: aggregate results \#

\begin{tabular}{|c|c|c|c|}
\hline \multirow[t]{2}{*}{ Cost Component } & \multicolumn{3}{|c|}{ Environmental Cost (per year) } \\
\hline & $\begin{array}{l}\text { Per Hectare } \\
\quad \text { (Rs.) }\end{array}$ & $\begin{array}{c}\text { Per Ton } \\
\text { of Soil } \\
\text { Loss } \\
\text { (Rs.) }\end{array}$ & $\begin{array}{l}\text { Total } \\
\text { (Rs.Milli } \\
\text { on) }\end{array}$ \\
\hline \multicolumn{4}{|l|}{ 1. On-Site Cost } \\
\hline (a) Value of Loss of Productivity Method (VLPM) & 3529 & 141 & 2553 \\
\hline (b) Value of Loss of Nutrients Method (NRCP) & 5068 & 203 & 3667 \\
\hline \multicolumn{4}{|l|}{ 2. Off-Site Cost } \\
\hline$\overline{\text { (a) Value of Loss of Irrigated Agriculture }}$ & 117.48 & 4.69 & 85.0 \\
\hline (b) Value of Loss of Hydro-Power Generation & 9.81 & 0.39 & 7.1 \\
\hline (c) Flushing cost of Kothmale Reservoir & 25.76 & 1.03 & 18.6 \\
\hline (d) O\&M cost of highways in the Upland & 103.20 & 4.13 & 74.7 \\
\hline (e) Cost of other off-site damages $* *$ & 51.26 & 2.05 & 37.1 \\
\hline Sub Total - Total Off-Site Cost & 307.51 & 12.29 & 222.5 \\
\hline \multicolumn{4}{|l|}{ 3. Total Environmental Cost $(3=1+2)$} \\
\hline (a) Based on (VLPM) & 3856 & 153 & 2775.6 \\
\hline (b) Based on (NRCM) & 5375 & 215 & 3888.8 \\
\hline $\begin{array}{l}\text { 4. Aggregate Farm Income Foregone } \\
\text { (Rs.Million/year) } \\
\text { 5. Aggregate Farm Income Foregone (Rs/hec/year) }\end{array}$ & & & 1506.06 \\
\hline $\begin{array}{l}\text { 6. Aggregate Market Margin Foregone } \\
\text { (Rs.Million/year) }\end{array}$ & 2081 & & \\
\hline \multirow[t]{2}{*}{ 7. Aggregate Market Margin Foregone (Rs/hec/year) } & & & 1047.07 \\
\hline & 1447 & & \\
\hline \multicolumn{4}{|l|}{$\begin{array}{l}\text { 8. Total Environmental Cost } \\
\text { (a) as a percentage of GDP }\end{array}$} \\
\hline (i) Based on VLPM & & & 0.72 \\
\hline (ii) Based on NRCM & & & 1.00 \\
\hline \multicolumn{4}{|l|}{$\begin{array}{l}\text { (b) As a percentage of Agriculture's Share of GDP } \\
\text { (i) Based on VLPM }\end{array}$} \\
\hline \multicolumn{4}{|l|}{ (ii) Based on NRCM } \\
\hline \multicolumn{4}{|l|}{$\begin{array}{l}\text { (c) As a Percentage of Total Value of Farmgate } \\
\text { Production in the Upland }\end{array}$} \\
\hline \multirow[t]{2}{*}{ (ii) Based on NRCM } & & & 0.24 \\
\hline & & & 0.33 \\
\hline \multicolumn{4}{|c|}{$\begin{array}{l}\text { ** The other off-site damages include downstream flood, health hazards, and cost of } \\
\text { purification of drinking water }\end{array}$} \\
\hline \multicolumn{4}{|c|}{$\begin{array}{l}\text { \#ata used to estimate the land degradation-induced on-site and off-site costs are not } \\
\text { included in this paper for space limitations. The data are available on request from } \\
\text { the author. }\end{array}$} \\
\hline
\end{tabular}

Source: Somaratne, (1999). 
Appendix Table 6: Projections of the effects of tariff reduction on onsite and off-site environmental cost (Rs. Million/ year)

\begin{tabular}{|c|c|c|c|c|c|c|}
\hline \multirow[t]{3}{*}{ Components } & \multicolumn{6}{|c|}{ Tariff Reduction } \\
\hline & \multicolumn{2}{|c|}{ Policy $1 *$} & \multicolumn{2}{|c|}{ Policy $2 * *$} & \multicolumn{2}{|c|}{ Policy $3 * * *$} \\
\hline & $\begin{array}{l}\text { VLPM } \\
\#\end{array}$ & $\begin{array}{c}\text { NRCM } \\
\text { \#\# }\end{array}$ & VLPM & NRCM & VLPM & NRCM \\
\hline 1. Base Case & & & & & & \\
\hline On-Site Cost & 2553.13 & 3666.32 & 2553.13 & 3666.32 & 2553.13 & 3666.32 \\
\hline Off-Site Cost & 224.89 & 224.89 & 224.89 & 224.89 & 224.89 & 224.89 \\
\hline $\begin{array}{l}\text { Total Environmental } \\
\text { Cost }\end{array}$ & 2778.02 & 3891.21 & 2778.02 & 3891.21 & 2778.02 & 3891.21 \\
\hline 2. With Policy & & & & & & \\
\hline On-Site Cost & 2543.75 & 3657.37 & 2534.3 & 3648.07 & 2512.17 & 3625.27 \\
\hline Off-Site Cost & 224.38 & 224.38 & 223.87 & 223.87 & 222.61 & 222.61 \\
\hline $\begin{array}{l}\text { Total Environmental } \\
\text { Cost }\end{array}$ & 2768.14 & 3881.76 & 2758.17 & 3871.94 & 2734.78 & 3847.88 \\
\hline 3. Net Policy Gains & & & & & & \\
\hline Total On-site Gains & 9.38 & 8.95 & 18.83 & 18.25 & 40.96 & 41.05 \\
\hline Total Off-site Gains & 0.5 & 0.5 & 1.02 & 1.02 & 2.28 & 2.28 \\
\hline $\begin{array}{l}\text { Aggregate Net Policy } \\
\text { Gains } \\
\text { 4. Value of Policy- } \\
\text { induced Net Gains as a } \\
\text { Percentage of }\end{array}$ & 9.89 & 9.45 & 19.85 & 19.27 & 43.24 & 43.33 \\
\hline $\begin{array}{l}\text { (a) Agriculture's share } \\
\text { of GDP }\end{array}$ & 0.01 & 0.01 & 0.02 & 0.02 & 0.04 & 0.04 \\
\hline (b) Total GDP & 0.003 & 0.003 & 0.005 & 0.005 & 0.011 & 0.012 \\
\hline $\begin{array}{l}\text { (c) Total Environmental } \\
\text { Cost }\end{array}$ & 0.36 & 0.24 & 0.72 & 0.50 & 1.58 & 1.13 \\
\hline
\end{tabular}

* Policy 1: $50 \%$ tariff reduction in non-plantation agricultural sectors only.

** Policy 2: $100 \%$ tariff reduction in non-plantation agricultural sectors only.

*** Policy 3: 50\% across-the-board tariff re2duction.

\# $\quad$ VLPM: Value of Loss of Productivity Method

\#\# NRCM: Nutrient Replacement Cost Method 